\title{
ASUSTUSNIMED KIILI VALLAS
}

\author{
TIINA LAANSALU
}

Annotatsioon. Artikkel annab ülevaate Kiili asustusnimede uurimusest, kus käsitletakse nii vanema kui ka hilisema kihistuse nimesid. Uurimuse aluseks on Eesti Keele Instituudi murdearhiivi kohanimekartoteegi materjal, mida on võrreldud vanemate kirjapanekutega. Vanimad asustusnimede ülestähendused pärinevad XIII sajandist, järgmiste sajandite andmeid leiab vakuraamatutest, revisjonikirjadest ja kaartidelt. Artikkel tutvustab Kiili asustusnimede vanust ja päritolu, rööpnimesid ning struktuuri. Antroponüümsete asustusnimede osatähtsus on XIX sajandi keskpaigast tunduvalt vähenenud, samas kui mitteantroponüümsete nimede osakaal on suurenenud. Omaniku perekonnanimest lähtuvaid rahvakeelseid rööpnimesid oli Kiili taludel mõnevõrra rohkem kui neid, mis lähtusid talu vanast nimest või uuemast hüüdnimest. Asulate puhul esineb rööpnimesid vähem. Struktuurianalüüsis on vaadeldud nimede liigitumist tüvede arvu järgi, nimede aluskäändevalemit, eriarenguid ning nimedes esinevaid murdejooni.

Võtmesõnad: onomastika, asulanimed, mõisanimed, külanimed, talunimed, rööpnimed

\section{Sissejuhatus}

Artikkel põhineb autori 2010. aastal Tartu Ülikoolis kaitstud magistritööl ${ }^{1}$ (Tärk 2010), mille eesmärk oli anda ülevaade Kiili valla asustusnimedest

1 Uurimuse analüüsiosa jaguneb kahte ossa, sisaldades esiteks asustusnimede loendit ning teiseks nende nimede vanuse ja päritolu, rööpnimede ja struktuuri analüüsi. Asustusnimeloend kujutab endast sõnastiku vormis nimistut, mis hõlmab järgmisi andmeid: 1) nime kirjakeelne kuju; 2) vajaduse korral nime kohalik hääldus lihtsustatud transkriptsioonis; 3) talunimede puhul alati küla(d), kus talu Eesti Keele Instituudi kohanimekartoteegi keelejuhtide andmete järgi asub (või asus), võimaluse korral on esitatud ka rööpnimi (-nimed) ning vajaduse korral on täpsustatud objekti asukohta ja/või lühidalt seda iseloomustatud; 4) nime varasemad leitud ülestähendused; 5) autori seisukoht nime päritolu kohta ning nime antroponüümsed ja apellatiivsed vasted; 6) toponüümiline võrdlusmaterjal, mis pärineb varasematest kohanimeuurimustest (Kallasmaa 1996; Kettunen 1955; Pall 1969; Simm 1973b). 
ja olla väikeseks jätkuks Eesti senistele regionaalsetele kohanimeuurimustele. Regionaalsed tööd on vajalikud seetõttu, et need loovad baasi, mille najal saab hakata tegema üldistavamaid uurimusi, mis haaravad kogu keeleala (Simm 1973b: 2). Kiili asustusnimede uurimus on uudne selle poolest, et tegemist on linnalähedase ala $^{2}$ nimedega, millest kohanimeuurijad on seni enamasti mööda vaadanud.

Valdava osa eesti asustusnimedest moodustavad talunimed. Lisaks kuuluvad asustusnimede hulka asulanimed: linnade, külade (ka külaosade) ja mõisate nimed (Kallasmaa 2005: 18). Küla- ja mõisanimesid ${ }^{3}$ on uurimuses käsitletud Valdek Palli (1977) eeskujul koos, kuna need on tihedalt seotud - tihtipeale sai mõis nime põliskülalt, mille asemele ta rajati, ning mõisanimed on omakorda sageli saanud hilisemate asunduste nimede aluseks.

\section{Uurimismaterjal}

Uurimuse aluseks on Eesti Keele Instituudi murdearhiivi kohanimekartoteegi materjal. Arhiivis leidus kokku 566 Kiili alale kuuluvat asustusnime (kogutud aastatel 1950 ja 1975-1981). Neist vanimate kohta pärinevad kirjalikud teated juba XIII sajandi algupoolelt - kaudselt 1241. aastaga dateeritud Taani hindamisraamatust „Liber Census Daniæ” (LCD) (Johansen 1933). LCD-s esitatud kohanimedest on näha, et sel ajal oli olemas enamik põliskülasid, mille asutamine ulatub seega tagasi kaugesse muinasaega, kusjuures nii mõnegi põlisküla asemele on hiljem rajatud mõis. Suurem osa vanematest töös kasutatud allikatest pärineb Eesti Ajalooarhiivist, lisaks on

Asustusnimistu rakenduslik eesmärk on olla Kiili valla kohanimekomisjonile abiks nimetamist vajavatele kohtadele nimede otsimisel. Uurimus saigi alguse Kiili valla pakkumisest uurida Kiili kohanimesid. Vald leidis, et vanad kohalikud nimed võiksid abiks olla näiteks uusasumitele toponüümide määramisel.

2 Kiili vald asub kunagise Jüri kihelkonna keskosas, Tallinnast ja Ülemiste järvest lõuna pool, Tartu maantee ja Viljandi maantee vahel, piirnedes idas Rae, lõunas Kose ja läänes Saku vallaga.

3 Kiili valla piirkonnas on asunud kolm mõisat: Kurna mõis, Sausti (ehk Suure-Sausti) mõis ja Nabala mõis. Kiili valda kuulub praeguse haldusjaotuse järgi kaks alevikku: Luige ja Kangru, ning 13 küla: Arusta, Kurevere, Lähtse, Metsanurga, Mõisaküla, Nabala, Paekna, Piissoo, Sausti, Sookaera, Sõgula, Sõmeru ja Vaela. Lisaks on alal eri aegadel olnud veel järgmised külad: Altjõe, Pealtjõe, Nabala-Mõisaküla, Nabala-Nõmmeküla, Padiküla, Raudalu, Saire, Mäe ja Siberiküla. 
vajalikke andmeid leitud ka Tallinna Linnaarhiivi kaardikogust. Materjali leidmisel olid abiks vakuraamatud aastatest 1661-1685. Veel on kasutatud 1687. ja 1697. aastal koostatud kaarte, aastail 1725-1726 korraldatud adramaarevisjoni materjali, aastaist $1782,1795,1811,1816,1834,1850$ ja 1858 pärinevaid hingeloendeid ehk revisjonikirju, 1835. aasta perekonnanimede panemise raamatut ning 1859.-1875. aastast pärinevaid kaarte ja plaane. Kuigi sajanditevanused kirjapanekud aitavad oletada kohanimede vanust, tuleb ometigi silmas pidada, et mida kaugemale minevikku, seda rohkem võib vanades dokumentides esineda lünki ja kirjapaneku juhuslikkust, ning nii ei ole võimalik öelda, et näiteks talu, mida revisjonikirjas pole märgitud, oleks päris kindlasti olnud hilistekkeline.

\section{Asustusnimed}

\subsection{Asulanimed}

Varaseimaid ülestähendusi külanimede kohta leiab LCD-st. Nende põhjal tuleb näiteks Harjumaa puhul ilmsiks väljakujunenud asustuspilt ja külade võrk, mis on olnud aluseks asustuse edasisele arengule (Troska 1995: 6). Külad olid alistatud ja lõpuks pärisorjastatud eesti talupoegade asulad, mis säilitasid oma sotsiaalse olemuse mitmete sajandite vältel ühesugusena (Troska 1987: 13). Ka külanimede praegusaegne kuju oli selleks ajaks juba välja kujunenud ning nende algset vormi on seetõttu väga keeruline ära arvata.

Ühe küla moodustas suurem või väiksem hulk talusid, mida sidus tolleaegne maakasutussüsteem: põllu-, heina- ja karjamaade ühine kasutamine. Veel XIX sajandi esimesest poolest pärinevad mõisaplaanid näitavad, et iga küla maad moodustasid üpriski tervikliku territooriumi. XIX sajandi teisel poolel kaotati aga vana maakorraldus, talusid hakati kruntima ja talurahvale müüma. Maa-asustus hakkas hajuma, sest paljud lahkusid külast ja kolisid oma krundile. Hajumine süvenes veelgi 1920. aastatel, mil viidi ellu maareform, mille alusel mõisamaad võõrandati, krunditi ja jagati. Maarahvastiku tugeva sotsiaalse diferentseerumise tõttu tekkis XIX sajandi jooksul vanade külade kõrvale palju uusi, peamiselt kehvikute väga väikese maaga majapidamistest koosnevaid külasid (või ka külaosi), mida nimetati saunaküladeks, mõnel pool ka vabat-, moona-, popsi- või kantküladeks. (Troska 1987: 13) Kiilis Nabala mõisas on 
kehvikmajapidamistest tekkinud näiteks Siberiküla, samuti on Kiili alalt kogutud andmeid nelja Saunaküla kohta.

Mõisatest kui feodalismiajastu suurmaavaldustest võib Eestis rääkida alates XIII sajandist (Johansen 1933: 271). Sellest ajast elas Eestis saksa ülemkiht, kes on siinsetele kohtadele ka omakeelseid nimesid andnud. Nii kasutati paralleelselt eesti ja saksa nimesid, mis enamasti olid omavahel keeleliselt seotud. Näiteks võib rohkesti laennimesid leida vanade feodaalmõisate eesti- ja saksakeelsete nimede seast. Mõisanimed ise on omakorda tihti saanud hilisemate asunduste nimede aluseks. Suurema osa mõisanimedest moodustavad possessiiv- ehk omandusnimed, st nimed, mis näitavad mõisa kuulumist kellelegi. Varasematel aegadel võis mõisa nimi muutuda, kui mõis läks uue omaniku valdusesse, hiljem kinnistus nimi mõisat märkima ükskõik missuguse peremehe valduses. (Uustalu 1968: 734) See tähendab, et algselt võis mõisat tähistada isikunimi, mis hiljem muutus kohanimeks, nagu oli omane ka taludele. XVII sajandil ilmub allikaisse täiesti uus liik mõisaid - abimõisad ehk kõrvalmõisad (nt Sausti mõisal Padiküla karjamõis ja Nabala mõisal Peebu karjamõis).

Asulanimesid leidus uuritud materjali hulgas 38. Peaaegu kolmandik Kiili ala asulanimedest oli kirjas juba Taani hindamisraamatus: Kurevere (LCD-s Kurkeuerce), Kurna (Queronoic), Lähtse (Lateis), Mõisaküla (Moises), Nabala (Napalce), Padiküla (Pattas), Paekna (Pakikanal), Sausti (Sauthcel), Sõgula (Seculis), Sõmeru (Someres) ja Vaela (Waioloe). XVII sajandil lisandusid Saire ja Sookaera. Selleks ajaks olid tekkinud ka Kurna ja Sausti mõisa rahvakeelsed nimed - vastavalt Treja ja Kaarepere. Mainitud on ka Peebu karjamõisa. XVIII sajandil lisandus Veneküla. Lisanimena on XVIII sajandi kirjapanekutesse ilmunud Raudalu ja Kiili ning XIX sajandil Aruste. Ülejäänud asulanimed (15 ehk 43\% Kiili asulanimedest) on hilisemad, nt Altjõe, Luige, Metsanurga, Mäe, NabalaNõmmeküla, Pealtjõe, Piissoo ja Siberiküla, külaosanimed Metsanurk ja Põrgunurk ning samuti Saunakülad. Hiline nähtus on ka ametlikus asjaajamises olnud tava jagada külasid mitmesse ossa, nt Mäe küla $>$ Mäe I ja Mäe II küla, Metsanurga küla > Metsanurga I ja Metsanurga II küla.

Põlistele asulanimedele on omane, et nad lähtuvad loodusnimest, vahel ka isikunimest. Kiili asulanimedest võib antroponüümsete nimede näiteks tuua Kaarepere, Peebu ja Treja ning võib-olla kuuluvad siia ka Kiili, Kurevere, Luige, Saire ja Sookaera. Mitteantroponüümseid nimesid paistab olevat rohkem, need võiksid olla näiteks Altjõe, Kurna, Lähtse, 
Metsanurga, Mõisaküla, Mäe, Nabala, Padiküla, Paekna, Pealtjõe, Raudalu, Sausti, Sõgula, Sõmeru ja Vaela.

Uuritud mõisanimed jagunevad kolmeks: 1) mõne siinsel lääniks saadud maa-alal asunud küla nimest lähtunud nimed, nt Kurna (Cournal), Nabala (Nappel), Sausti (Sauß), ka karjamõisa nimi Padiküla (Paddiküll); 2) saksa mõisnike perekonnanimedest lähtunud nimed, nt Kaarepere ( $<$ Scharenberg), Treja $(<$ Treyden); 3) ees- või lisanime alusel tekkinud nimed, nt karjamõisa nimi Peebu (Pebo).

\subsection{Talunimed}

Talunimede funktsioon on sama, mis ülejäänud pärisnimedel - eristada referenti teistest sama tüüpi referentidest. Enamjaolt on talunimede puhul eristavaks teguriks olnud omanikule viitamine, mis on ka loomulik, kuna igal talul oli ise omanik. Teine suurem kriteerium talude eristamisel on olnud nende asukoht. (Lehikoinen 2005: 8-9) Talunimede tekkeaja kohta info puudub, esimesed andmed Eesti talunimede kohta on XVI sajandist. Need pärinevad vakuraamatutest ja revisjonikirjadest, kus märgiti üles isikuid. Üldiseks nimevormeliks Eesti talupoegade ülestähendamisel oli lisanimi ja eesnimi. (Kallasmaa 2001: 30) Lisanimi, mis iseloomustas nimekandja ametit, lisateenistusala, harjumusi, päritolu või muud, oli alguses arvatavasti seotud ühe konkreetse isikuga ning hakkas alles hiljem tähistama ka tema peret ja talukohta, muutudes põlvest põlve kanduvaks ${ }^{4}$ (Simm 1973a: 400). Lisanimede muutumine püsivateks talunimedeks kulges eri piirkondades järk-järgult ja pika aja jooksul. Kõige varem said püsinime hajatalud, mis omaette asuvate ja külast eraldatud maavaldustega moodustasid iseseisvaid asustusüksusi. Kiilist võiks näiteks tuua Kurna mõisas asunud Ihuvere ja Aru hajatalu (1697. aasta kaardil Ihoffer ja Arro Jöri).

Veel XIX sajandi esimese ja teise kümnendi kirjapanekuis on sageli märgitud peale talunime resp. lisanime ka peremehe eesnimi, hilisemates revisjonikirjades on aga enamasti esitatud ainult talunimi (Pall 1977: 167). Ka Kiili valla talude puhul kasutatakse 1816. aasta revisjonis (mõnel pool

4 Mõned nimeuurijad on püsivaid lisanimesid nimetanud ka perenimedeks (vt Palli 1959: 605). Siin tutvustatavas uurimuses on siiski kasutatud mõistet lisanimi, kuna perenimi on tänapäeva keelekasutuses mitmetähenduslik, märkides mõnikord ka perekonnanime. 
veel ka 1834. aasta revisjonis) talude märkimiseks lisanime koos peremehe eesnimega, hilisemates revisjonides on aga enamasti talunimi kirjas peremehe nimest eraldi, nt Sõmeru küla Kaasiku talu: 1816 Kasiko Mart, 1834 Kasik; Paekna küla Kalamäe talu: 1816 Kallamäe Tomas, 1834 Kallamae; Mõisaküla Mihkle talu: 1834 Michkle Jaan, 1835 Michkle.

Perekonnanimede panek XIX sajandi esimesel poolel kaotab vajaduse lisanimede järele ning sajandeid kestnud nimetamissüsteem hääbub (Linnus 1971: 106). Perekonnanimede panemisel sai talunimest tihti ka antroponüüm ehk isikut tähistav nimi, sest omanikku nimetati juba tarvituses kinnistunud talunime järgi. Samas on see protsess töötanud ka vastupidises suunas - kui perekonnanimed juba eksisteerisid, võidi talule taas omaniku järgi nimi panna, kasutades nüüd selleks juba omaniku perekonnanime. (Lehikoinen 2005: 10-11) Perekonnanimeks oli suuremaid eeldusi saada kõige vanematel, põlistalunimedel, uusasukad valisid aga enamasti talunimest erineva perekonnanime (Kallasmaa 1988: 485).

Kairit Henno arvates näitavad allikad, et talunimede ja isikunimede vastastikune mõju pole kunagi olnud vaid ühesuunaline, vaid on kõigil aegadel olnud kahesuunaline (Henno 2000: 19). Ka uuemal ajal ilmnes vana tava nimetada talusid ja perede elukohti seal elavate inimeste nimede, hilisemal ajal valdavalt perekonnanimede järgi. Näiteks asundustalude (moodustatud 1920. aastatel) rahvakeelsed nimed on enamasti lähtunud omanike perekonnanimedest ning vahetunud koos peremeeste vahetumisega, kusjuures talude ametlikke nimesid igapäevases kõnepruugis tihti ei tarvitatagi.

Uuritud talunimed jagunevad ajaliselt nelja rühma: 1) aastatel 16611726 kirjapanekutesse ilmunud nimed (57 nime), 2) aastatel 1782-18345 lisandunud nimed (70 nime), 3) aastatel 1835-1875 lisandunud nimed (49 nime), ning 4) hilise kihistuse nimed ehk nimed, mis puuduvad uuritud vanemates dokumentides (352 nime). Nimede jaotumist saab vaadata ka jooniselt 1 .

\footnotetext{
5 Ajalises mõttes kõrvuti asetsevate 1834. aasta revisjonikirja ja 1835. aasta perekonnanimede panemise raamatu materjal on eraldi rühmadesse jaotatud, kuna perekonnanimede panekul lisandus uus alus nime tekkimiseks või tekitamiseks ning seega sobivad 1835. aasta kirjapaneku andmed ühte rühma uuemate revisjonikirjade omadega, kus perekonnanimed samuti rolli mängivad.
} 


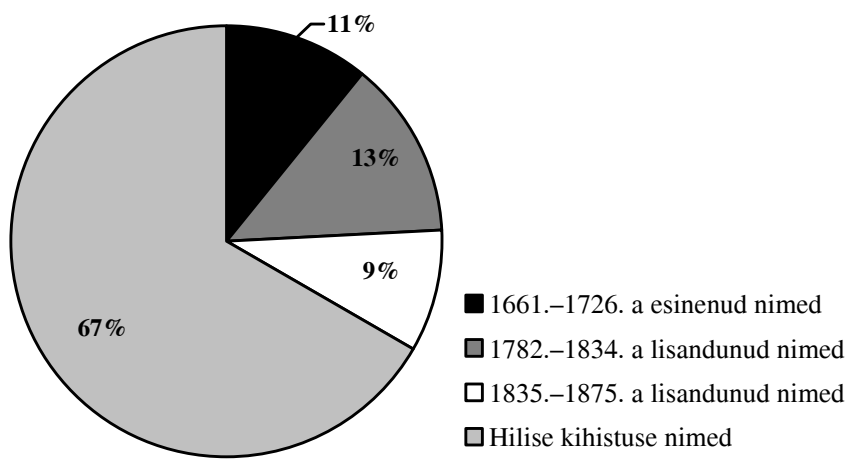

Joonis 1. Talunimede jaotumine vanuse järgi

528 talunimest on hilise kihistuse nimesid 352 (ehk 67\%) ja vanema kihistuse nimesid 176 (ehk 33\%). Vanema kihistuse nimede liigitamisel päritolu järgi on eeskujuks võetud Valdek Palli talunimeanalüüs raamatus „Põhja-Tartumaa kohanimed II” (1977). Pall liigitab talunimesid esmalt tekkeaja järgi, lähtudes sellest, millistes revisjonikirjades leidub vaste tänapäeval eksisteerivale nimele, ning seejärel analüüsib talunimede päritolu eri vanusega nimedes. Päritolu alusel jagab ta nimed kahte rühma. Esimesse rühma kuuluvad isikunimedest lähtuvad ehk antroponüümsed talunimed - nendeks on peamiselt eesnimest, aga ka omaniku elukutset, tegevusala, päritolu, iseloomuomadusi vms märkivast lisanimest lähtuvad nimed. Samuti kuuluvad sellesse rühma looma- ja linnunimetustest pärinevad nimed, kuna need on isikunimede ja lisanimedega väga tihedalt seotud. Teise rühma moodustavad Palli järgi mitteantroponüümsed nimed - need on nimed, mille lähtealuseks on talu asukoht, mõne hoone nimetus või looduseseme nimetus.

Kiili vanimate talunimede rühma (allikaisse ilmunud 1661-1726) kuulub 57 nime: 32 antroponüümset nime (56\%) ja 20 mitteantroponüümset nime (35\%), päritolu jäi määramata viiel nimel (9\%). 1782.-1834. aasta revisjonikirjades lisandus eelmistele veel 70 nime: 40 antroponüümset nime (57\%) ja 27 mitteantroponüümset nime (39\%), päritolu jäi määramata kolmel nimel (4\%). 1835.-1875. aasta kirjapanekutes lisandus 49 talunime: 15 antroponüümset nime (31\%) ja 34 mitteantroponüümset nime (69\%). Vanema kihistuse talunimede jagunemist antroponüümse ja mitteantroponüümse päritolu järgi saab vaadata jooniselt 2 . 


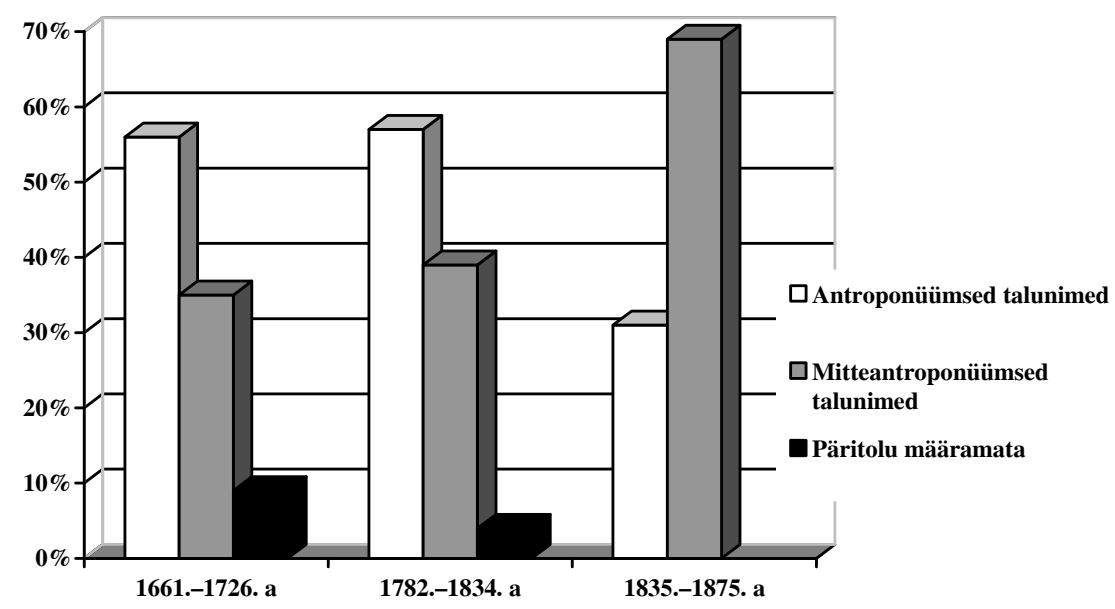

Joonis 2. Antroponüümsete ja mitteantroponüümsete talunimede osatähtsuse muutumine vanemate talunimede seas

Mida hilisem on nimi, seda läbipaistvam ta on, seetõttu on ka järjest väiksem nende nimede hulk, mille päritolu pole teada. Kui kohanimi ei ole läbipaistev, st ei ole nimekasutajale teadaolevate isikunimede või apellatiivide sarnane, on võimalik, et tegu on väga vana nimega, mis on kas tugevalt lühenenud või on vastav prooprium või apellatiiv üldkeelest kadunud. Nii on ka see teadmine, et nimi on raskesti etümologiseeritav, omal moel väärtuslik.

Jooniselt 2 nähtub, et antroponüümset päritolu nimede osatähtsus on XIX sajandi keskpaigast tunduvalt vähenenud, samas kui mitteantroponüümsete nimede osakaal on suurenenud. Eriti palju on lisandunud loodusnimedest pärinevaid talunimesid: aastail 1661-1726 kirja pandud nimedest on selliseid talunimesid 26\%, aastail 1782-1834 lisandunutest 27\% ning aastail 1835-1875 lisandunutest juba 47\%. Arvatavasti tingis antroponüümsete talunimede osatähtsuse järsu vähenemise see, et XIX sajandi alguses hakati talusid esimest korda üles märkima talunimede, mitte enam peremeeste nimede järgi. Kui talupojad pärisorjusest vabastati, hakkasid mõisale talupoegade asemel kuuluma vaid talud ja maa ning tekkis vajadus talunimede järele. Vanematele taludele sobis tihti nimeks juba talunimerollis kasutuselgi olnud lisanimi, nt Kureveres Uueveski: 1687 Ufweweski Jürgen, 1834 Ueweskÿ; Lähtses Annuse: 1726 Hannusse Mart, 
1834 Annusse; Nabalas Kahu: 1687 Kacho Hanss, 1834 Kahho. Võib aga arvata, et just uuematele talukohtadele, kus kunagine lisanimi ei olnud talukohta tähistama kinnistunud, pandi nimepanekul pigem talu ennast kui selle peremeest iseloomustav nimi - ehk siis mitteantroponüümne nimi, nt Kureveres Kuivajõe: 1811 Kuiwajoe Hans, 1834 Kuiwajoeggi; Sõmerus Väljataguse: 1816 Wäliataguse Tomas, 1834 Wäljataggo.

Hilise kihistuse talunimesid iseloomustab loodusesemete nimetuste ja sekundaarnimede rohkus. Kiili hilise kihistuse talunimede hulgas leidub loodusesemete nimetusi, nt Aasa ja Karjamaa, ning sekundaarnimesid, nt Pudrusoo ja Kipramäe. Korduvalt esinevad loodusnimetustest pärinevad talunimed, nagu Aaviku (3), Allika (2), Kangru (4), Kase (3), Kivi (2), Kruusiaugu (2), Kunsiku (2), Lepiku (2), Männiku (3), Pärna (2), Salu (2) ja Tamme (2).

Hilise kihistuse talunimed erinevad vanadest talunimedest ka selle poolest, et neil on palju rohkem rööpnimesid. Uuemaid elukohti nimetati peaaegu alati omaniku järgi, kuigi kinnistutel olid olemas ka ametlikud nimed. Asundustalude rahvakeelne nimi on enamasti lähtunud omaniku perekonnanimest ning vahetunud tavaliselt koos peremehe vahetusega. Vähemal määral on rahvakeelseks nimeks ka peremehe eesnimi, nt Hansu, Illari, Kaljula, Kostja, Mati ja Reinu. Samuti on asundustalu mõnel puhul saanud nime mõisa hoonelt, mille läheduses või mail ta asus, nt Rehe ja Veski.

Rööpnimerohkusele lisaks ilmneb hiliste talunimede puhul erinevus ka nimede käänamisel. Tavapärane talunime Nõmme käänamine oleks Nõmmele : Nõmmel, kuid hilisemat nime, mis tähistas küll talukohta, kuid oli arvatavasti veel väga tugevalt peremehega seotud, käänati Nõmme juurde : Nõmme juures (Raudalus, Nõmm oli peremehe perekonnanimi).

\subsection{Rööpnimed}

Rööpnimedeks ehk paralleelnimedeks nimetatakse neid kohanimesid, mida kasutatakse paralleelselt ühe ja sama objekti tähistamiseks, kusjuures tihtipeale rakendatakse nimevariante ise kontekstides. Rööpnimed on talletatud põhiliselt Eesti Keele Instituudi kohanimekartoteegis.

Taludel on sageli mitu rööpnime rahvapäraste nimevariantide näol, mis on lisandunud ametlikele katastrinimedele. Alates XIX sajandi lõpupoolest hakati väiketalude nimedena fikseerima perekonnanimesid, üldiseks muu- 
tus see nimemall 1920. aastate asundustalude puhul, kus ametlikku nime teadis sageli vaid talu peremees (Pajusalu jt 2002: 288). Perekonnanimede laialdane kasutamine just uute talude tähistamisel kinnitab inimeste põlist tava pere elukohta ehk talu nimetada eeskätt elanike järgi.

Rööpnimedega talusid oli uuritavate seas 85 (20\% taludest) ja nende nimetamiseks on kasutatud kokku 180 nime, mis moodustab 528 Kiili talunimest $34 \%$. Ühel talul esines viis rööpnime, ühel talul neli, viiel talul kolm ning ülejäänud 78 talul kaks rööpnime. Rööpnimedeks loetakse ühelt poolt dokumentides fikseeritud ametlikke talunimesid ja teiselt poolt rahva hulgas kasutatud, esimestest täiesti erinevaid nimesid, mis jagunevad üldjoontes kaheks: 1) peremehe perekonnanimest (harva ka eesnimest) lähtuvad rööpnimed, ja 2) talukoha vanast nimest või uuemast hüüdnimest lähtuvad rööpnimed (Troska 1995: 67-68). Kiilis oli omaniku perekonnanimest lähtuvaid rahvakeelseid rööpnimesid (nt $\underline{\text { Vaheri }}=$ Ilula ja $\underline{\text { Orava }}$ $=$ Kuusiku) mõnevõrra rohkem kui neid, mis lähtusid talu vanast nimest

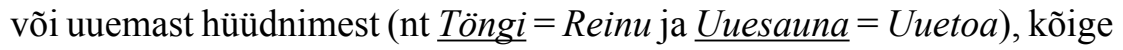
vähem oli peremehe eesnimest pärinevaid rahvakeelseid rööpnimesid (nt $\underline{\text { Illari }}=$ Luige ja $\underline{\text { Kostja }}=$ Nellise).

Rööpnimedeks ei loeta nime modifikatsioone, lühenemise või rahvaetümoloogia teel muutunud nimevorme (nt Ihure Ihuvere, Aruna Arumaa), assotsiatiivselt moodustatud nimesid (nt Gabira $=$ Krapiiva, Pada $=$ Poti) ega hargtäiendiga nimesid. Viimased sündisid seetõttu, et ilmnes vajadus eristada samasuguse nimega talusid. Selleks lisati ühele või mõlemale eristamist vajavale nimele mingi hargtäiend, nt Arusta = Jaani-Arusta, Kaasiku = Kaasiku-Sepa, Loo = Loo-Jüri, Manni = Manni I= Sausti-Manni, Manni = Manni II = Manni-Kõrtsu = Nabala-Manni. Niisuguste nimevariantide puhul leiab tihtipeale aset rööpnimedesarnane rööpkasutus ning need võiksid tegelikult moodustada kolmanda rööpnimerühma.

Asulate puhul esines rööpnimesid vähem - 12 protsendil. Leidus kaks rööpnime, mis pärinevad mõisniku perekonnanimest: Kurna mõisa rööpnimi Treja $<$ Treyden ja Sausti mõisa rööpnimi Kaarepere $<$ Scharenberg. Ka küladel esines rööpnimesid: Nabala-Nõmmeküla = Saunaküla ja Piissoo = Saunaküla. Lisaks kasutati asulanimede puhul nimevariante, nt Kurna-Mõisaküla $=$ Mõisaküla, Nabala $=$ Nabala-Mõisaküla, Sausti $=$ Suure-Sausti . Kahjuks ei leidu rahvapärase asulanimekasutuse kohta eriti andmeid - rööpnimesid võis kasutusel olla enam, kuid neid ei ole kirja pandud. 


\section{Asustusnimede struktuur}

\subsection{Liht- ja liitnimed}

Nimed on rühmitatud Valdek Palli (1977: 43-71) sõnatüvelise jaotuse eeskujul lihtnimedeks ja liitnimedeks. Uuem süntaktilis-semantiline struktuurimudel teeb vahet liitnimedel ja mitmest leksikaalsest elemendist koosnevatel lihtnimedel, kuid kuna asustusnimed ongi ülekaalukalt viimast liiki, siis räägitakse siin liitnimedest liitunud sõnatüvede alusel. Liitnimedeks on liigitatud ka need lühenenud nimed, mis algselt on olnud liitnimed, kuid mida praegune keelekasutaja võib nime tausta teadmata struktuuri järgi lihtnimeks arvata, nt talunimi Väljari, mis on lühenenud nimest Välja-Jüri.

\subsubsection{Lihtnimed}

Lihtnimesid on Kiili asustusnimede hulgas 340, mis moodustab $60 \%$ kõigist Kiili asustusnimedest. Kõigi lihtnimede aluskäändevalem ${ }^{6}$ on $\mathrm{K}_{1 \mathrm{Gen}}$. Sagedasimad lihtnimed on Lepiku (6), (H)allika (5), Aaviku (4), Kangru (4), Mäe (4), Männiku (4), Aru (3), Härma (3), Kase (3), Kuusiku (3), Luige (3), Nõmme (3), Rebase (3) ja Vainu (3). Küllaltki suur osa korduvatest nimedest on hilised nimed (esile saab tõsta Kase, Luige ja Männiku talu, millest ühegi nimi ei olnud põline). Leidus ka kaks abstraheerunud kollektiivsufiksiga nime: Saarusti (varieerub nimega Saaruste) ja Sausti. Lokatiivse ja kollektiivse sufiksiga asustusnimed (28) jagunevad järgmiselt: 12 la-sufiksiga nime (nt Ilula, Kaljula, Kivila), 14 iku- ja stiku-liitelist nime (nt Aaviku, Kaasiku; Kivistiku, Kuristiku) ning kaks vere-liitelist nime (Ihuvere, Kurevere). Kiili asustusnimede seas leidus ka üks nimi, mida võiks liigitada terminnimeks ${ }^{7}-$ Suvila.

\footnotetext{
6 Aluskäände mõiste võttis kasutusele Valdek Pall (1968: 155). Aluskääne näitab nime algvormi kuju: nimi oma algvormis on mõne tegeliku või mõeldava mittenime vormi kujuline, nt apellatiiv kask, genitiiv kase, aga talunime algvorm on genitiivikujuline Kase, seega nime aluskääne on genitiiv. K tähistab valemites käändsõna ja H hargtäiendit.

7 Terminnimi on kohanimi, kus objekti liiki märkiv sõna ise ongi nimi.
} 


\subsubsection{Liitnimed}

Liitnimesid on Kiili asustusnimede hulgas kokku 226 ehk 40\% kõigist Kiili asustusnimedest. Neist kõige sagedasemad on Saunaküla (4), Alttoa (3), Kasemetsa (3), Kruusiaugu (3), Uuesauna (3) ja Väljaotsa (3). 197 erikujulisest liitnimest on neljaosalisi nimesid üks ( $0,5 \%$ kõigist erikujulistest liitnimedest): Kurna-Mõisaküla, mis on moodustunud apellatiividest koer + oja + mõis + küla. Kolmeosalisi nimesid on 13 (6,5\%), neist liitsõnalise esimese komponendiga nimesid üheksa, nt Veeroja-Juuliuse, Jõeä̈̈re I ja Metsari-Hansu (Metsari < Metsa-Jüri) ning liitsõnalise teise komponendiga nimesid neli: Nabala-Mõisaküla, Nabala-Nõmmeküla, Uus-Arupere ja Uus-Metsari (Metsari< Metsa-Jüri).

Ülejäänud 183 liitnime (93\%) on kaheosalised. Kaheosalised liitnimed liigituvad esimeste komponentide sõnaliigi alusel nelja rühma: 1) nimisõnalise esimese komponendiga nimed (143 nime ehk 78\%), 2) omadussõnalise esimese komponendiga nimed (25 nime ehk 14\%), 3) eessõnade abil moodustatud nimed ( 9 nime ehk 5\%), ning 4) nimed, mille esimese komponendi sõnaliiki ei ole võimalik määrata (6 nime ehk 3\%). Sagedasemad esimesed komponendid on Aru- (7), Uue- (7), Vana- (6), Tõnu- (5), Loo- (4), Metsa- (4), Tamme- (4) ja Välja- (4). Ilmneb, et ühed enim esimesi komponente moodustavad sõnad on omadussõnad uus ja vana. Binaarne opositsioon Uue-vs. Vana- moodustab Vladimir Toporovi (2008: 285) järgi toponüümilise mikrosüsteemi, mille on tinginud asjaolu, et on tulnud teha vahet kahe samase koostisosaga nime vahel (nt eraldati Mäe talust uus talukoht ning see nimetati Uuemäeks, samas kui senist Mäe talu hakati kutsuma Vana-Mäeks). Rohkesti esimesi komponente on andnud ka loodusnimed (eriti aru, loo, metsa, tamme, välja) ja eesnimed (eriti Tõnu).

Teise nimekomponendi sõnaliigi järgi jaotuvad kaheosalised liitnimed kolme rühma, millest arvukaima moodustavad nimisõnalise teise komponendiga nimed (174 nime ehk 95\%). Seitsme nime teine komponent on moodustatud arvsõnade abil (4\%) ning kahe nime oma tagasõnade abil (1\%). Kõige sagedasem teine komponent on -mäe (29 esinemiskorda). Järgnevad -sauna (7), -jõe (6), kõrts (6), -küla (6), -otsa (6), -aru (5), -Jüri (5), -maa (5), -Mardi (5), -metsa (5), -oja (5), -sepa (5), -soo (5), -välja (5), -augu (4), -toa (4), ametlikes nimedes ka II 'teine' (4), I 'esimene' (3) jne. Nagu näha, on -mäe teise komponendi positsioonis sageduse poolest ülejäänutest kaugel ees. Marja Kallasmaa järgi (2000: 110-111) on 
genitiivne -mäe asustusnimede teise komponendina nii levinud seetõttu, et asulaid püüti rajada just kõrgematele kohtadele.

Aluskäändevalemi järgi eristuvad järgmised liitnimerühmad:

1) $\mathrm{K}_{1 \mathrm{Nom} / \mathrm{Gen}}+\mathrm{K}_{2 \mathrm{Gen}}$, nt Aasnurme, Allikapaju, Külaotsa, Mardihansu, Nurgamäe, Põdrasauna, Tammsaare, Tõnujaani, Uueveski, Uustalu;

2) $\mathrm{H}+\mathrm{K}_{1 \mathrm{Gen}}$, nt Jaani-Arusta, Mardi-Arusta, Nabala-Manni, SaustiManni, Suure-Sausti;

3) $\mathrm{H}+\left(\mathrm{K}_{1 \mathrm{Nom} / \mathrm{Gen}}+\mathrm{K}_{2 \mathrm{Gen}}\right)$, nt Uus-Arupere, Nabala-Mõisaküla, Nabala-Nõmmeküla;

4) $\mathrm{K}_{1 \mathrm{Nom} / \mathrm{Gen}}+\mathrm{K}_{2 \mathrm{Gen}}+\mathrm{H}$, nt Jõeääre I, Jõeääre II;

5) $\mathrm{K}_{1 \mathrm{Nom} / \mathrm{Gen}}+\mathrm{K}_{2 \mathrm{Nom}}$. See aluskäändevalem iseloomustab nimesid, kus $\mathrm{K}_{2}$ on tegelik determinant. Vaadeldud liitnimeliste asustusnimede hulgas leidus selliseid nimesid kaheksa: kõrtside nimed Kiili kõrts, Kõvera kõrts, Luige kõrts, Pääsukese kõrts, Raudalu kõrts ja Tammetalu kõrts ning külaosade nimed Metsanurk ja Põrgunurk.

\subsection{Eriarengud}

Lisaks vaadeldi nimedes aset leidnud eriarenguid: ebareeglipäraseid lühenemisi, sarjasiirdumisi, rahvaetümoloogiat ja mugandumisi.

Ebareeglipäraselt lühenenud asustusnimede hulgas leidus nimesid,

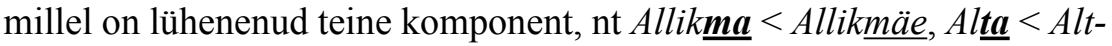
$\underline{\text { toa }}$, Harjuva $<$ Harjuoja, Ihure $<$ Ihuvere, Kurna $<*$ Koiranoja, Põldme

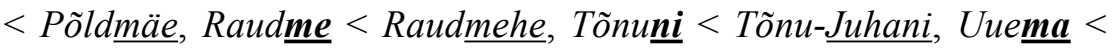
Uuemaa, Väljari < Välja-Jüri. Lühenenud esimene komponent on nimel Kurna (urna $<*$ Koiranoja) ja võimalik, et ka nimel Toajaagu (Toajaagu $<$ ? Tuha-Jaagu). Muu hulgas ilmnes, et lühenenud nimedest päris paljude puhul oli kogumise ajal kasutusel nii lühenenud kui ka lühenemiseelne nimekuju. Võib arvata, et mõnevõrra takistab nimede püsivat lühenemist ametlikumas keelekasutuses kasutatav veel lühenemata nimekuju kui korrektsemaks peetav nimevariant, mis ei lase kõnekeeles teisenenud ja lühenenud nimekujul ainukasutatavaks muutuda.

Sarjasiirdumisi on kahte tüüpi:

1) -mäe - $m a(a)$ vaheldumine: Eerumäe $\sim$ Eerumaa, Eris $\underline{m a ̈ e} \sim$ Erisma, Kõrgemäe $\sim$ Kõrgemaa, Mändmäe $\sim$ Mändmaa;

2) -selja -silla vaheldumine: Kirjasselja $\sim$ Kirjassilla. 
Rahvaetümoloogia on Kiili asustusnimede puhul muutnud vähemalt kaht nime: nimest Eruma on tekkinud nimi Eerumaa (nime kujunemise arvatav ahel: Geroma $>$ Jeruma $>$ Eruma $>$ Eerumaa), samuti võib olla rahvaetümoloogia tekitanud hüüdnimest rööpnime Hallionku ( $<$ Hallingu).

Mugandatud on Kiili asustusnimedest peamiselt just neid nimesid, mis on pärinenud mõnest võõrnimest, suuremas osas just Veneküla peremeeste vene eesnimedest, nt Eerumaa $<$ Eruma $<$ Jeruma $<$ Geroma $<$ Jeremei; Paali $<$ Pavel; Penduska $<$ Pentelei; Sahkari $<$ Zahhari, aga ka saksa mõisnike perekonnanimedest, nt Kaarepere < Scharenberg; Treja $<$ Treyden.

\subsection{Murdejooned}

Praeguse Kiili valla territoorium asub kunagise Jüri kihelkonna aladel. Jüri murrak kuulub põhjaeesti peamurde tuumalasse, Eesti suurima murdeala - keskmurde alale, täpsemalt keskmurde tuumalasse, kuhu kuuluvad Kesk-Tallinnamaa murrakud (Pajusalu jt 2002: 147). Järgnevalt ongi välja toodud Kiili asustusnimedes esile kerkinud keskmurdepärased jooned.

Mõne nime puhul ilmnes pikkade madalate vokaalide diftongistumine ja vahel ka konsonandi $v$ tekkimine sõna algusesse diftongi ette, nt talunime Aasnurme hääldus oasnurme, Aadu hääldus vuadu või Sääse hääldus siase. Pikkade keskkõrgete vokaalide diftongistumine avaldus järgmistes nimekujudes: küöbi (Kööbi), ’pietre (Peetri), söedi (Söödi), tiearu (Teearu). Assimileerumine $l j>l$ 'l esines nt Kiili talunimede häälduskujudes väl'lari (Väljari) ja 'al'la (Halja). Algupäraste diftongide järelkomponendi alanemist teises vältes võis täheldada näiteks talunimes Lauri $>$ Laari.

Keskmurde tuumalale omastest joontest esinesid:

1) järgsilpides $k s$-i püsimine, mis on eeskujuks olnud ka laennimede käänamisel (nt Andrekse, Annukse ja Tõnikse);

2) hilisdiftongides algse vokaali püsimine ning ka keskkõrgete vokaalide kõrgenemine (nt nimehääldus alttua);

3) pika $\ddot{u}$ diftongistumine (nt nimehääldus 'tüistre), ka pikk $\tilde{o}$ on võinud diftongistuda (nt Sõeru).

Lisaks ilmnes ka muid, üldisemaid murdelisi ja häälikuloolisi jooni:

1) afrikaadi säilimine omadussõnalise algupäraga nimisõnas karjane (Karjatse); 
2) er-ja el-lõpuliste sõnade $e$-tüveline käändumine, nt Köstre, Mihkle, Nikre ja Pärtle;

3) Kiili asustusnimede varasemad kirjapanekud võivad toetada oletust, et algupäraste diftongide järelkomponendi alanemine teises vältes on arvatavasti toimunud XIX sajandil, nt $a u>a a$ : 1782, 1811 Jauna Mart, 1835, 1850 Jana;

4) diftongi teise komponendi alanemine $a i>a e \sim a a$, nt külanimedes Vaela ja Paekna, vrd vanemaid kirjapanekuid: 1241 Waioloe, 1368 Waile, 1547 Wayllakulle, 1697 Waiell, 1726 Waila ning 1349 Paykenalle, 1478 Paikenall, 1541 Paeykenna, 1687 Paickna, 1782 Paickna;

5) genitiivi $n$ on säilinud nimes Kurna (< koiran 'koera' + oja). Genitiivi $n$ esineb ka nt nime Mõisaküla vanemates üleskirjutustes (1388 Moysenküll, 1548 Mosenkull). Sellest nähtub, et tunnus esineb uuritud kirjapanekutes just vanades liitnimelistes külanimedes esimese komponendi järel;

6) sisekaota nimekujud, nt Kurevere: 1241 Kurkeuerce, samuti Paekna: 1241 Pakikanal, 1349 Paykenalle, 1444, 1493 Paikenall, 1481 Paykenal;

7) XVII ja XVIII sajandi paiku kadus põhjaeesti murdeist sõnaalguline $h$. Selle kohta on näiteid ka Kiili asustusnimede varasemates kirjapanekutes, nt Allikmäe: 1687 Hallikmeh Jak, 1726 Allickmeh Thomas; Annuse: 1726 Hannusse Mart, 1782 Annosse Matz; Opmanni: 1697 Hopman Hans, 1782 Hopmanni Jaan, 1795 Opmanni Jaan.

\section{Kokkuvõte}

Asustusnimed on vanim kohanimerühm, mille kohta leidub kirjalikke andmeid. Nimede kirjalikesse allikatesse ilmumise aeg lubab oletada nende vanust, samuti aitab kirja pandud nimekuju määrata nime võimalikku päritolu ja esitada neid andmeid abiks võttes nimede etümoloogiaid. Samas tuleb arvesse võtta, et esitatud etümoloogiate tõesuses ei saa alati kindel olla, kuna ka vanemaid kirjapandud kohanimesid võib olla juba mõjutanud rahvaetümoloogia, nimeuurijaid võib päritolu kindlakstegemisel eksitada homonüümia, nimede kunagist kirjapanekut on võinud mõjutada kirjutaja keeleline taust jne. Kuigi sajanditevanused kirjapanekud aitavad 
määrata kohanimede arvatavat vanust, tuleb ometigi silmas pidada, et mida vanem dokument, seda rohkem võib selles esineda lünki ja kirjapaneku juhuslikkust, ning seetõttu ei ole võimalik öelda, et näiteks talu, mida revisjonikirjadesse pole märgitud, on kindlasti hilistekkeline.

Asustusnimede vanust, arvatavat päritolu ja struktuuri arvesse võttes on lihtsam seletada vanu nimesid, saada aru uute nimede tekkemehhanismidest ning mõista nimedega toimunud muutusi, nii reeglipäraseid kui ka ebareeglipäraseid. Siinkohal tuleks korrata Marja Kallasmaa sõnu, mille kohaselt on võimalik, et kohanimede areng pole muud kui rahvaetümoloogiliste tõlgenduste ahel ning ehk polegi õige otsida, milline neist tõlgendustest on „õige”, „tõene” või „usaldusväärne” - võib-olla on nad kõik õiged, igaüks oma ajaetapil. (Kallasmaa 2005: 30). Nii võib nimede liigitamine olla vahel tahtmatult meelevaldne, kuid asustusnimede olemuse ja arengu kohta ülevaatlikuma pildi andmiseks on see siiski vajalik.

\section{Kirjandus}

Henno, Kairit 2000. Eesti priinimed: Jaani kihelkond. Tallinn: Eesti Keele Sihtasutus.

Johansen, Paul 1933. Die Estlandliste des Liber Census Daniae. KopenhagenReval.

Kallasmaa, Marja 1988. Muutuv ja püsiv nimemaailm. - Keel ja Kirjandus 8, 477-485.

Kallasmaa, Marja 1996. Saaremaa kohanimed I. Toim. Helmi Neetar. Tallinn: Eesti Keele Instituut.

Kallasmaa, Marja 2000. Saaremaa kohanimed II. Toim. Tiina Lias. Tallinn: Eesti Keele Instituut.

Kallasmaa, Marja 2001. Eesti talunimed ja germaani isikunimede probleem. Congressus nonus internationalis fenno-ugristarum: 7.-13.8.2000, Tartu. Pars V, Dissertationes sectionum: linguistica. II / redegit: Tõnu Seilenthal; curaverunt: Anu Nurk, Triinu Palu. Tartu: Paar, 30-33.

Kallasmaa, Marja 2005. Estonian settlement names. - Onomastica Uralica 3. Settlement Names in the Uralian Languages. Ed. by Sándor Maticsák. Debrecen-Helsinki, 17-33.

Kettunen, Lauri 1955. Etymologische Untersuchung über estnische Ortsnamen. Helsinki: Suomalainen Tiedeakatemia.

Lehikoinen, Laila 2005. Finnish house names and their connection with surnames. - Onomastica Uralica 3. Settlement Names in the Uralian Languages. Ed. by Sándor Maticsák. Debrecen-Helsinki, 7-15. 
Linnus, Jüri 1971. Põhja-Eesti talupoegade lisanimedest 18. sajandil. - Emakeele Seltsi aastaraamat 17 (1971). Tallinn, 99-108.

Pajusalu jt 2002 = Karl Pajusalu, Tiit Hennoste, Ellen Niit, Peeter Päll, Jüri Viikberg. Eesti murded ja kohanimed. Toim. Tiit Hennoste. Tallinn: Eesti Keele Sihtasutus.

Pall, Valdek 1968. Eesti kohanimede struktuurist. - Keel ja Kirjandus 3, $147-158$.

Pall, Valdek 1969. Põhja-Tartumaa kohanimed I. Toim. Madis Norvik. Eesti NSV Teaduste Akadeemia Keele ja Kirjanduse Instituut. Tallinn: Valgus.

Pall, Valdek 1977. Põhja-Tartumaa kohanimed II. Toim. Madis Norvik. Eesti NSV Teaduste Akadeemia Keele ja Kirjanduse Instituut. Tallinn: Valgus.

Palli, Heldur 1959. Eesti isikunimedest Harju- ja Järvamaal XVI sajandil. - Keel ja Kirjandus 10, 595-608.

Simm, Jaak 1973a. Elukutset ja päritolu märkivad Võnnu talunimed. - Eesti NSV Teaduste Akadeemia Toimetised. 22. köide. Ühiskonnateadused. $\mathrm{Nr} 4,400-407$.

Simm, Jaak 1973b. Võnnu kihelkonna asustusalane toponüümika. Väitekiri filoloogiakandidaadi teadusliku kraadi taotlemiseks. Käsikiri Eesti Keele Instituudis.

Toporov, Vladimir 2008. Teoreetilise toponomastika valdkonnast. - Nimetamise strateegiatest Eesti kultuuris. Toim. Ülle Pärli, Eva Lepik. Tartu: Tartu Ülikooli Kirjastus, 274-289.

Troska, Gea 1987. Eesti külad XIX sajandil. Ajaloolis-etnograafiline uurimus. Tallinn: Eesti Raamat.

Troska, Gea 1995. Talunimed läbi aegade. Tallinn: Teaduste Akadeemia kirjastus.

Tärk, Tiina 2010. Kiili valla asustusnimed. Magistritöö. Käsikiri Tartu Ülikooli eesti ja üldkeeleteaduse instituudis ning Tartu Ülikooli kodulehel; http:// dspace.utlib.ee/dspace/bitstream/10062/15080/1/tark_tiina.pdf.

Uustalu, Koidu 1968. Mõisate ja mõisnike nimedest lähtunud kohanimesid Lõuna-Eestis. - Keel ja Kirjandus 12, 734-746. 


\title{
Settlement names in Kiili municipality
}

\author{
Tiina Laansalu
}

The paper provides a survey of the settlement names used in the municipality of Kiili, Harju county. As a regional study it is intended to become a brick in the foundation for more general studies covering the whole language area. The material for the study comes from the place name archives of the Institute of the Estonian Language. Besides the list of Kiili settlement names the study contains an analysis of the date and origin of the names, as well as their parallel names and structure. The names have been dated using some sources from 1241-1875. The analysis revealed that since the mid- $19^{\text {th }}$ century the proportion of anthroponymic names has considerably dropped and that of non-anthroponymic ones has increased while especially many recent farm names derive from the names of natural objects. One might assume that the steep drop in the number of anthroponymic farm names is due to liberation from serfdom; removal of peasants from estate property while keeping lands and buildings, created a need for naming the farms that earlier used to be called by the names of their owners, resp. families. Recent farm names often originated in natural names, secondary names, master's surnames, or, more rarely, first names. Twenty per cent of farms had parallel names, whereas of the settlements only twelve per cent had parallel names. By structure the settlement names studied were classified into simple names and compound names. The simple names included abstracted names, names with a locative or collective suffix, and term names. The compound names were classified by the number of components, as well as by parts of speech. The study also deals with irregular shortening, group transition, folk etymology, adaptation, and a few dialectal features in Kiili settlement names.

Keywords: onomastics, settlement names, estate names, village names, farm names, parallel names

Tiina Laansalu

soome-ugri keelte ja murrete osakond

Eesti Keele Instituut

Roosikrantsi 6

10119 Tallinn

Tiina.Laansalu@eki.ee 